The Rise and Fall of the Paraguayan Republic, $1800-1870$ 
THIS PAGE INTENTIONALLY LEFT BLANK 
Latin American Monographs, No. 48 Institute of Latin American Studies The University of Texas at Austin 
THIS PAGE INTENTIONALLY LEFT BLANK 


\title{
The Rise and Fall of the Paraguayan Republic, 1800-1870
}

\author{
by John Hoyt Williams
}

\section{its}

Institute of Latin American Studies

The University of Texas at Austin 
International Standard Book Number 0-292-77017-0 (paper)

0-292-77016-2 (cloth)

Library of Congress Catalog Card Number 78-620052

Copyright $(\mathcal{O} 1979$ by John Hoyt Williams

All Rights Reserved

The Latin American Monographs Series

is distributed for the Institute of

Latin American Studies by:

University of Texas Press

P. O. Box 7819

Austin, Texas 78712 